\title{
Availability of E-commerce Support for SMEs in Developing Countries
}

\author{
Mahesha Kapurubandara ${ }^{1^{*}}$, Robyn Lawson ${ }^{2}$ \\ ${ }^{1,2}$ Locked Bag 1797, Penrith South DC, NSW 1797, Australia \\ mahesha@scm.uws.edu.au,r.lawson@uws.edu.au
}

Revised: 11 September 2008; Accepted: 21 July 2008

\begin{abstract}
Although research indicates e-commerce offers viable and practical solutions for organizations to meet challenges of a predominantly changing environment, the few available studies related to SMEs in developing countries reveal a delay or failure of SMEs in adopting ICT and e-commerce technologies. The various factors identified as causes for the reticence can be broadly classified as Internal Barriers and External Barriers. This paper presents a model for barriers to adoption of ICT and e-commerce based on the results of an exploratory pilot study, survey and interviews of SME intermediary organization. It identifies support for SMEs in Sri Lanka with regard to ICT and e-commerce. It also determines a strong need for necessary support and discusses the availability of the support.
\end{abstract}

Keywords: e-commerce, SME, adoption, developing countries, barriers, support.

\section{INTRODUCTION}

Developing countries have the potential to achieve rapid and sustainable economic and social development by building an economy based on an ICT-enabled and networked SME (Small and Medium-sized Enterprise) sector, capable of applying affordable yet effective ICT solutions [1]. It is accepted that e-commerce contributes to the advancement of SME business in developing countries [2]. With the development of ICT and the shift to a knowledge-based economy, e-transformation and the introduction of ICT is becoming an increasingly important tool for SMEs both to reinvigorate corporate management and promote growth of the national economy[1]. E-commerce technologies facilitate organizations to improve their business processes and communications, both within the organization and with external trading partners [3].

However, the adoption of ICT and e-commerce in developing countries has fallen below expectations [2], as they face unique and significant challenges in adopting ICT and e-commerce [4]. Nevertheless, it is imperative for SMEs to adopt e-commerce technologies to survive in intense competitive national and global markets.

The SME sector plays a significant role in its contribution to the national economy in terms of the wealth created and the number of people employed [5]. Forging ahead SMEs need to accept the challenges, including the barriers as they move towards successful adoption of available technologies while raising awareness of relevant support activities and preserving limited available resources to avoid severe repercussions from costly mistakes.

This paper contributes to the ability to understand factors that inhibit ICT and e-commerce adoption in SMEs in Sri Lanka, a developing country on its way to an e-society. Believing that research findings from Sri Lanka will prove to be useful for other developing countries it explores how best the barriers could be overcome by way of support activities. The paper first outlines current research into adoption in developing countries, discussing models for adoption by previous research and presents a framework established for use with this research. The research methodology and the results are subsequently discussed.

\section{THEORETICAL FRAMEWORK}

\section{SMEs in Sri Lanka}

SMEs everywhere play a critical role in economic development, and Sri Lanka is no exception. Many countries use different parameters to define SMEs by referring to: number of employees, amount of capital invested or amount of turnover [6]. In Sri Lanka a clear definition of a SME is absent with government agencies using different criteria to define SMEs [6, 7]. The National Development Bank (NDB), the Export Development Board (EDB), and Industrial Development Board (IDB) use value of fixed assets as the criterion, whereas the Department of Census and Statistics (DCS), Small and Medium Enterprise Development (SMED), and the Federation of Chambers of Commerce and Industry (FDCCI) use number of employees as criteria [7].

Following the World Bank definition, for this study we consider enterprises with 10-250 employees as SMEs [6]. The 2004 mission statement of the International Labour Organization (ILO) reported that $75 \%$ of Sri Lanka's labour force was employed in the SME sector depicting SMEs' contribution towards employment and income generation.

The domestic market is the main outlet for SMEs. SMEs are also sub-contracted to large exporters with larger entrepreneurs coordinating direct exports as is seen with coir - based products, wood, handicrafts, 
plants and foliage. If Sri Lanka wishes to ride high on the electronic highway it should provide Sri Lankan SMEs 'a ramp to the digital highway' and stimulate e-commerce. This is supported by the government's e-Sri Lanka vision, championed by the Information and Communication Technology Agency of Sri Lanka (ICTA), aiming to harness ICT as a lever for economic and social advancement.

\section{Barriers to ICT and e-commerce Adoption by SMEs}

Developing countries face insurmountable barriers getting on to the electronic highway. Yet, it is encouraging to note existing research to identify barriers in a variety of factors grouped into several categories. A number of authors $[8,9]$ group such factors into three major categories: owner/manager characteristics, firm characteristics, costs and return on investment. Support for SMEs to adopt e-commerce technologies, demand consideration for each of these categories.

While diversity among owner/managers and the decision makers for SMEs, reflects on a number of factors towards adoption of e-commerce technologies it can be concluded that factors affecting adoption relate to owner/manager characteristics. A significant factor here is little or no knowledge, firstly of the technologies, and secondly of the benefits from such technologies. This is a major barrier to the take up of e-commerce [10], lack of knowledge on how to use the technology and low computer literacy, mistrust of the IT industry and lack of time also hinders the adoption. SME owners, concerned about a return on their investments, are reluctant to make substantial investments particularly since shortterm returns are not guaranteed [11].

Other factors, such as the current level of technology usage within the organization related to the characteristics of the organization, also affect adoption of e-commerce [10]. The Organization for Economic Co-operation and Development (OECD (1998) has identified that: lack of awareness; uncertainty about the benefits of electronic commerce; concerns about lack of human resources and skills; set-up costs and pricing issues; and, concerns about security as the most significant barriers to e-commerce for SMEs in OECD countries. Low use of e-commerce by customers and suppliers, concerns about security, concerns about legal and liability aspects, high costs of development, limited knowledge of e-commerce models and methodologies, and unconvincing benefits to the company are among other factors [12]. SMEs definitely have limited resources (financial, time, personnel). This "resource poverty" has an effect on adoption, as they cannot afford to experiment with technologies and make expensive mistakes [13].

\section{Barriers to e-commerce in Developing Countries}

If governments believe that e-commerce can foster economic development it is necessary to identify inherent differences in developing countries with diverse economic, political, and cultural backgrounds to understand the process of technology adoption [9]. SME studies of e-commerce issues in developed countries [14-16] indicate issues faced by SMEs in developed countries can be totally different. Organizations adopting ICT and e-commerce in developing countries face problems like: lack of telecommunications infrastructure, lack of qualified staff to develop and support e-commerce sites, lack of skills among consumers needed in order to use the Internet, lack of timely and reliable systems for the delivery of physical goods, low bank account and credit card penetration, low income, and low computer and Internet penetration $[4,17,18]$. Lack of telecommunications infrastructure includes poor Internet connectivity, lack of fixed telephone lines for end user dial-up access, and the underdeveloped state of Internet Service Providers.

Disregard for e-commerce is not surprising where shopping, a social activity in Sri Lanka, recognizes face-to-face contacts as important. Distrust of what businesses do with personal and credit card information in countries where there may be good justification for such distrust, could become a serious obstacle to ecommerce growth $[18,19]$.

Absence of legal and regulatory systems inhibits development of e-commerce in developing countries. A study of SME adoption of e-commerce in South Africa found that adoption is heavily influenced by factors within the organization [12]. Lack of access to computers, software/hardware, affordable telecommunications, low e-commerce use by supply chain partners; concerns with security and legal issues; low knowledge level of management and employees; and unclear benefits from e-commerce were found to be major factors that inhibit adoption. Similar study in China found that limited diffusion of computers, high cost of Internet and lack of online payment processes directly inhibit e-commerce. Inadequate transportation and delivery networks, limited availability of banking services, and uncertain taxation rules indirectly inhibit e-commerce adoption.

A study in Egypt [20] found main contributory factors to non-adoption include: awareness and education, market size, e-commerce infrastructure, telecommunications infrastructure, financial infrastructure, the legal system, the government's role, pricing structures, and social and psychological factors. A comparison of two studies in Argentina and Egypt suggests key factors affecting e-commerce adoption in developing countries are: awareness, telecommunication infrastructure, and cost. The Internet and e-commerce issues of SMEs in Samoa are consistent with the studies conducted in other developing countries [21]. Studies in Sri Lanka revealed inhibiting factors as: lack of knowledge and awareness about benefits of e-commerce, current un-preparedness of SMEs to adopt e-commerce as a serious business concept, insufficient exposure to IT products and services, language barriers and lack of staff with IT capability [7]. Web-based selling was not seen as practical as there is limited use of Internet banking and Web portals, as well as inadequate telecommunications 
infrastructure [7].

Thus, available literature reveals significant factors dealing with internal and external barriers that can be grouped to develop a framework for investigations affecting adoption of e-commerce technologies.

Internal Barriers: SMEs can control internal factors categorising them into: Individual (owner/ manager), Organizational and barriers related to cost or return on investments.

External Barriers: Those that cannot be resolved by the SME organization and are compelled work within the constraints. Inadequate telecommunication infrastructure and legal and regulatory framework are examples of external barriers. These could be further subdivided into: infrastructure related, political, social and cultural and legal. Some external barriers could be addressed by clustering sharing expenses, resources and facilities.

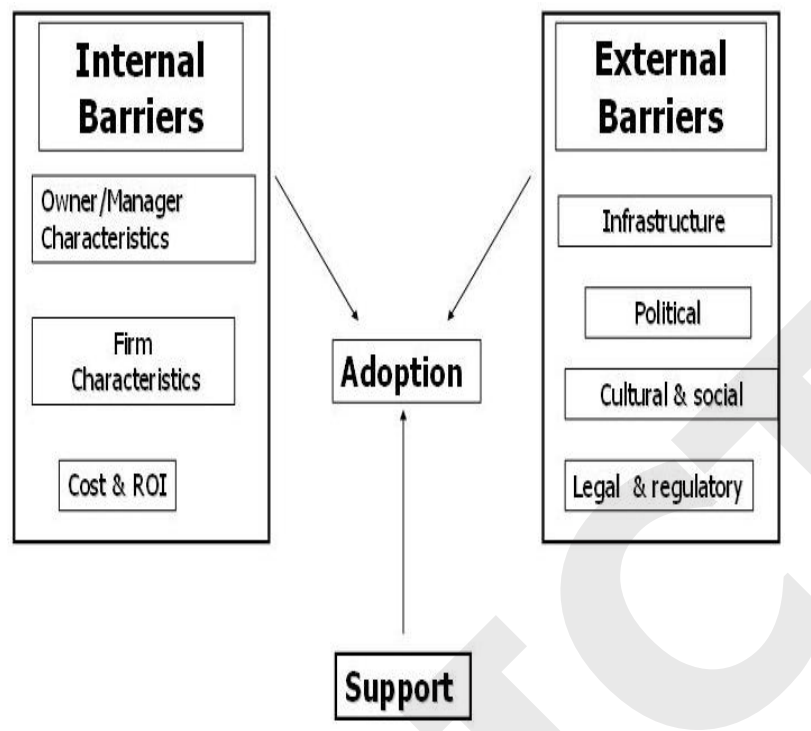

Figure 1: Conceptual Model - Barriers to Adoption

\section{RESEARCH METHODOLOGY}

Empirical research in this area being limited, an exploratory investigation utilizing qualitative and quantitative evidence was considered most suitable. The research centred round SMEs in Colombo District with the highest density of companies using ICT. Colombo district was the base for investigations with SME selection necessitating employee strength of 10-250 employees; not totally immature but somewhat versatile in the use of ICT and e-commerce.

The study was conducted in two stages preliminary pilot interviews, a survey, and interviews with SME intermediary support organizations According to Mingers[22], the use of such multiple methods is widely accepted as providing increased richness and validity to research results, and better reflects the multidimensional nature of complex real-world problems. Besides, a multimethod approach allows for the combination of benefits of both qualitative and quantitative methods, and permits empirical observations to guide and improve the survey stage of the research [23, 24].
The preliminary pilot interviews brought in barriers imperative to SMEs with the model (Figure 1) and the survey instrument, forming outcome from interviews and observations supported by an extensive literature review. The survey and interviews with intermediary support organizations followed. Face-toface interviews were semi-structured to gather qualitative empirical data and provide flexibility [25] as they allow researchers to explore issues raised by respondents, generally not possible through questionnaires or telephone interviews.

The research was carried out in three stages. Stage 1: was the Pilot Exploratory Study withSMEs, Stage 2: Survey of the SME organisation using a questionnaire and Stage 3: Interviews with intermediary SME Organisations.

The research approach has been discussed elsewhere [26] and therefore it suffices to discuss the results in the following section.

\section{RESULTS DISCUSSION}

Barriers: Pilot Interviews: A majority (88\%) of respondents ranked lack of awareness the most significant barrier.This can be attributed to the fact that the majority of owner/managers, described themselves as basically computer literate. Knowledge of available technologies or suitability for effective use towards improved productivity for benefits was negligible. They appear to be confused with choices in software/hardware. Computers, were underutilized with adhoc purchases and isolated implementation shadowing ICT strategy; a major concern, being decision makers. Next, was the cost of Internet, equipment and e-commerce implementation. Inadequate telecom infrastructure chosen by $83 \%$ was the third most frequently cited barrier chosen by the more advanced in usage of ICT using e-mail and Internet, more likely to have experienced problems. Unstable economy, political uncertainty, lack of time, channel conflict, lack of information about e-commerce and lack of access to expert help, was cited as barriers by $70 \%$ of respondents.

Analysis of Survey data: More than $75 \%$ of the respondents ( $96 \%$ males and $4 \%$ females) were either professionally qualified or graduates. Of the Tables produced below, Table 1 identifies the top 6 internal barriers of 9 listed. Table 2 shows external barriers, divided into Cultural, Infrastructure, Political, Social, and Legal and Regulatory. Tables 4 and 5 illustrate internal and external support needed. Analysis of survey results reveal that lack of skills, lack of awareness of benefits and return on investments prevent SMEs from adopting ICT and e-commerce technologies, reinforced by "awareness and education" ranking top for support by nearly $90 \%$ of the respondents, not surprising for a developing country like Sri Lanka trying to implement technologies. It reflects on other internal barriers too and awareness and education can, to a great extent, counter this barrier. Since use of ICT in Sri Lanka is low, e- 
commerce faces inhibition and does not suit business transactions.

"Lack of popularity in online marketing" and "low Internet penetration" rate high in the list of external barriers. Improving ICT diffusion in Sri Lanka can address this problem. 'Inadequate infrastructure' impedes SMEs as reinforced by their request for "improvement of national infrastructure" raking very high on the support needed. SMEs in Sri Lanka are adversely affected by the high cost and unreliable service of infrastructure services such as electricity and telecommunications. The steps taken by the government to improve telecommunication facilities breaking telecom monopoly is noteworthy. Policy inertia and the lack of legal and regulatory framework also rank high and enforce constraints on SMEs. Policy reforms introduced by governments support the large export-oriented foreign direct investments leaving SMEs with ad-hoc policy prescriptions and weak institutional support [27]. The government's role in an overly bureaucratic regulatory system results in delays in its deliberations and is extremely costly [27]. Appropriate legal and regulatory framework would ensure that SMES operate on a level playing field.

Social barriers come next. A one-stop shop facility helps SMEs access information, technology, markets, and the much needed credit facilities. This concept, implemented for export-oriented foreign direct investments (EOFDI) by the Board of Investments (BOI) found it to be successful. Being policy makers working towards progress of SMEs, senior management lacking in ICT knowledge is identified as an important constraint directly impacting operational efficiency of SMEs. Awareness building and education with regard to ICT and technologies would help to alleviate this problem. Government, academia, and industry sectors can take leadership roles in promotion of ICT by conducting awareness and training programs, technical and non-technical catering to the needs of SMEs at grass-roots level. SMEs place a very heavy reliance on external advice and support. Such support and advice seem unavailable.

Perceptions of the SME Intermediaries: The intermediaries, with a consensus for awareness building programs at national level agree lack of awareness and lack of skills are major barriers for SMEs to adopt technologies. Training programs; workshops and seminars conducted in the local language need to be especially designed for SMEs at grass roots level.

Absence of a "one-stop shop" for advice and support is de-motivating and affects SMEs. It is fundamental to educate senior management of government organizations prior to providing support for SMEs with ICT and e-commerce. SMEs need not only ICT technologies but also quality control and standards. Inter-institutional coordination, staff development, and institutional capacity are also vital. Much effort seems replicated and wasted with public sector, private and non-governmental SME intermediary organizations working in isolation. The government is best equipped to reach rural SMEs at grass roots level. Tapping and utilizing all available strengths in a more coordinated manner would prove much more productive.

\section{Analysis of Barriers and Support}

This section discusses the extent to which the barriers are addressed by the support provided by the SME intermediary organization. The Table 5 and Table 6 given below illustrate the barriers that ranked as most significant, Table 7 identifies the support required to alleviate the barriers and table 8 indicates whether support is available by the SME intermediary organisations.

\section{Barriers}

The internal barrier "employees lacking the required skills are ranked the highest in the list". The interviews with the intermediary organizations reveal that this barrier is addressed only partially. While they admit that the SMEs need skill training from the grass root level, they are not in a position to deliver that support as they do not have the resources nor the mechanism to address that barrier. "Security concerns with payments" ranked next on the list. Support is not available from the intermediaries and they are not in a position to provide any support in this regard. The next two barriers on the list can be addressed with awareness building programs. The intermediaries do not seem to be addressing that fully.

Table 1: Internal Barriers to using or extending use ICT \& e-commerce

\begin{tabular}{llccc}
\hline \multicolumn{1}{c}{ Internal Barriers } & Mean & Std & N & \% \\
\hline Staff lack required skills & 3.88 & 1.35 & 120 & 66.6 \\
$\begin{array}{l}\text { Security concerns with payments over the } \\
\text { internet }\end{array}$ & 3.64 & 1.28 & 118 & 66.9 \\
$\begin{array}{l}\text { e-commerce cannot give a financial gain } \\
\text { N }=\text { number of organisations }\end{array}$ & 3.64 & 1.24 & 108 & 62.0 \\
\end{tabular}


Table 2: External Barriers to using or extending use of ICT \& e-commerce

\begin{tabular}{|c|c|c|c|c|}
\hline External Barriers & Mean & Std & $\mathbf{N}$ & $\%$ \\
\hline \multicolumn{5}{|l|}{ Cultural Barriers } \\
\hline $\begin{array}{l}\text { Lack of poularity for online marketing and sales } \\
\text { Infrastructure Barriers }\end{array}$ & 3.56 & 1.28 & 120 & 62.5 \\
\hline Low internet penetration in the country & 3.78 & 1.09 & 125 & 71.2 \\
\hline Inadequate quality and speed of lines & 3.63 & 1.06 & 130 & 70.8 \\
\hline Inadequate infrastructure in the country & 3.52 & 1.22 & 125 & 62.4 \\
\hline \multicolumn{5}{|l|}{ Political Barriers } \\
\hline Unstable economic climate in the country & 3.73 & .971 & 135 & 73.3 \\
\hline $\begin{array}{l}\text { Changing regulations with each govermment } \\
\text { change }\end{array}$ & 3.72 & 1.12 & 135 & 71.9 \\
\hline \multicolumn{5}{|l|}{ Social Barriers } \\
\hline Lack of information on e-commerce & 3.59 & 1.04 & 133 & 69.1 \\
\hline No one-shop facility & 3.50 & 1.19 & 127 & 54.3 \\
\hline No access to reliable expert help & 3.25 & 1.10 & 130 & 52.8 \\
\hline $\begin{array}{l}\text { Senior management in other sector lack ICT } \\
\text { knowledge }\end{array}$ & 3.24 & 1.05 & 123 & 52.8 \\
\hline \multicolumn{5}{|l|}{ Legal \& Regulatory Barriers } \\
\hline $\begin{array}{l}\text { Little support for SMEs from govermment and } \\
\text { industry associations }\end{array}$ & 3.7 & .96 & 128 & 64.0 \\
\hline $\begin{array}{l}\text { Inadequate legal framework for business using } \\
\text { e-commerce }\end{array}$ & 3.68 & .98 & 121 & 64.5 \\
\hline No simple procedures and guidelines & 3.67 & 1.10 & 128 & 65.6 \\
\hline $\begin{array}{l}\text { Lack of suitable software standards } \\
\mathrm{N}=\text { number of organisations }\end{array}$ & 3.51 & 1.10 & 128 & 53.9 \\
\hline
\end{tabular}

Table 3: Internal Support for SMEs to use or extend use of ICT \& e-commerce

\begin{tabular}{|c|c|c|c|c|c|c|c|}
\hline Internal Support & Mean & & Std & & $\mathbf{N}$ & & $\%$ \\
\hline Awareness and education & & .87 & & 132 & & 79.9 & \\
\hline $\begin{array}{l}\text { Guidance in overcoming risks associated with } \\
\text { implem entation }\end{array}$ & 3.86 & & .92 & & 129 & & 78.0 \\
\hline Guidelines for appropriate hardware and software & 3.78 & & .88 & & 134 & & 72.4 \\
\hline Advice and direction for ICT and e-commerce & 3.70 & & .91 & & 135 & & 70.4 \\
\hline $\mathrm{N}=$ number of organisations & & & & & & & \\
\hline
\end{tabular}

Table 4: External Support for SMEs to use or extend use of ICT \& e-commerce

\begin{tabular}{|c|c|c|c|c|}
\hline External Support & Mean & Std & $\mathbf{N}$ & $\%$ \\
\hline Improve national infrastructure & 4.04 & .76 & 130 & 84.6 \\
\hline Provide financial assistance & 3.97 & .81 & 135 & 78.5 \\
\hline Provide tax in centives & 3.97 & .92 & 132 & 80.3 \\
\hline Improve ICT diffusion & 3.95 & .83 & 130 & 80.8 \\
\hline $\begin{array}{l}\text { Government \& industry sector to take } \\
\text { leadership/promotion role }\end{array}$ & 3.91 & .91 & 134 & 75.4 \\
\hline Improve collaboration among SMEs & 3.86 & 1.04 & 133 & 69.1 \\
\hline $\begin{array}{l}\text { Improve low bank account and credit card } \\
\text { penetration }\end{array}$ & 3.83 & .81 & 123 & 72.4 \\
\hline $\begin{array}{l}\text { Enforce suitable software standards } \\
\mathrm{N}=\text { number of organisations }\end{array}$ & 3.8 & .97 & 132 & 74.3 \\
\hline
\end{tabular}


Table 5: Internal Barriers

\begin{tabular}{|l|l|l|}
\hline \multicolumn{1}{|c|}{ Internal Barriers } & $\begin{array}{c}\text { Required } \\
\text { Support }\end{array}$ & $\begin{array}{l}\text { Is Support } \\
\text { Available? }\end{array}$ \\
\hline $\begin{array}{l}\text { Employees lack the } \\
\text { required skills }\end{array}$ & Training & Minimal \\
\hline $\begin{array}{l}\text { Security concerns with } \\
\text { payments over the } \\
\text { Internet }\end{array}$ & $\begin{array}{l}\text { Legal } \\
\text { framework }\end{array}$ & No \\
\hline $\begin{array}{l}\text { e-commerce cannot give } \\
\text { any financial gains }\end{array}$ & Awareness & Minimal \\
\hline $\begin{array}{l}\text { e-commerce not suited to } \\
\text { the way we do business }\end{array}$ & Awareness & Minimal \\
\hline
\end{tabular}

Table 6: External Barriers

\begin{tabular}{|c|c|c|}
\hline External Barriers & $\begin{array}{l}\text { Required Sup- } \\
\text { port }\end{array}$ & $\begin{array}{l}\text { Is Support } \\
\text { Available? }\end{array}$ \\
\hline $\begin{array}{l}\text { Lack of popularity for } \\
\text { online marketing \& } \\
\text { sales }\end{array}$ & Awareness & No \\
\hline $\begin{array}{l}\text { Low Internet penetra- } \\
\text { tion in the country }\end{array}$ & $\begin{array}{l}\text { Awareness and } \\
\text { Infrastructure }\end{array}$ & No \\
\hline $\begin{array}{l}\text { Poor speed \& quality } \\
\text { of line with telecom- } \\
\text { munications }\end{array}$ & Infrastructure & No \\
\hline $\begin{array}{l}\text { Inadequate infrastruc- } \\
\text { ture in the country }\end{array}$ & Infrastructure & No \\
\hline $\begin{array}{l}\text { Relatively high cost } \\
\text { of internet access }\end{array}$ & Infrastructure & No \\
\hline $\begin{array}{l}\text { Unreliable power } \\
\text { supply }\end{array}$ & Infrastructure & No \\
\hline $\begin{array}{l}\text { Unstable economic } \\
\text { climate in the country. }\end{array}$ & & No \\
\hline $\begin{array}{l}\text { Constant change of } \\
\text { rules and regulations }\end{array}$ & & No \\
\hline $\begin{array}{l}\text { The lack of avail- } \\
\text { able information on } \\
\text { e-commerce }\end{array}$ & Awareness & Partially \\
\hline $\begin{array}{l}\text { No one shop facility } \\
\text { for services }\end{array}$ & One stop shop & No \\
\hline $\begin{array}{l}\text { Snr. Management } \\
\text { lacking in ICT knowl- } \\
\text { edge }\end{array}$ & Training & Minimal \\
\hline $\begin{array}{l}\text { No access to reliable } \\
\text { expert help }\end{array}$ & Consultancy & Minimal \\
\hline $\begin{array}{l}\text { Little support from } \\
\text { government/industry } \\
\text { with policies }\end{array}$ & $\begin{array}{l}\text { Legal frame- } \\
\text { work }\end{array}$ & No \\
\hline $\begin{array}{l}\text { Inadequate legal } \\
\text { framework for using } \\
\text { e-commerce }\end{array}$ & legal framework & No \\
\hline $\begin{array}{l}\text { No simple procedures } \\
\text { and guidelines }\end{array}$ & legal framework & No \\
\hline $\begin{array}{l}\text { Lack of suitable soft- } \\
\text { ware standards }\end{array}$ & legal framework & No \\
\hline
\end{tabular}

The above table 6 illustrates that in order to resolve the external barriers, support in infrastructure, awareness building, education, and training and consultancy is required. The SME intermediaries are helpless in providing the support with infrastructure and legal framework as the government intervention is required. The lack of availability of information and the lack of popularity of e-commerce can both be addressed by appropriate awareness building programs. Even though it is available to a certain extent, the SME intermediaries are not capable of proving fullest support to address this barrier due to lack of proper mechanism to reach the SMEs at grass root level. Even though the intermediaries are making an effort to generate awareness, they also seem to be hindered by finances and resources and lack of properly formulated strategies and coordinated programs.

\section{Support}

The survey results revealed the support strongly requested by the SMEs. The Tables 8 and 9 given below illustrate the support that ranked as most significant, within the organization: internal support and outside the organization: external support. It identifies the support required to assist them and also whether support is available with the SME intermediary organizations.

Table 7: Internal Support

\begin{tabular}{|l|l|}
\hline Internal Support Requested by SME & $\begin{array}{l}\text { Is Support } \\
\text { Available? }\end{array}$ \\
\hline $\begin{array}{l}\text { Guidance to overcome risks with } \\
\text { implementing }\end{array}$ & No \\
\hline $\begin{array}{l}\text { Awareness building/educating in ICT } \\
\text { \& e-commerce }\end{array}$ & Partially \\
\hline $\begin{array}{l}\text { Assist SMEs with guidelines for hard- } \\
\text { ware and software }\end{array}$ & No \\
\hline $\begin{array}{l}\text { Advice \& direction with regard to ICT } \\
\text { \& e-commerce }\end{array}$ & No \\
\hline
\end{tabular}

Guidance to overcome risks with implementing e-commerce ranked highest in the list of support for SMEs. They need support in every aspect of the implementation of e-commerce starting with knowledge, technical, management, and consultancy. This support is not available from the SME intermediary organizations. Assisting with hardware and software and also advice and direction is minimal and almost non-existent. It could also be contributed to the fact that the main focus of the intermediaries is first and foremost to elevate the standard of SMEs in general. Adoption of e-commerce has taken a back seat in view of the other pressing problems. 
Table 8: External Support

\begin{tabular}{|l|c|}
\hline \multicolumn{1}{|c|}{ External Support } & $\begin{array}{c}\text { Is Support } \\
\text { Available? }\end{array}$ \\
\hline Improving national infrastructure & No \\
\hline $\begin{array}{l}\text { Provide some form of financial assis- } \\
\text { tance to help SMEs }\end{array}$ & No \\
\hline $\begin{array}{l}\text { Government \& industry sector to } \\
\text { take leadership \& promotion }\end{array}$ & No \\
\hline Provision of tax Incentives & No \\
\hline $\begin{array}{l}\text { Improve low computer \& internet } \\
\text { penetration }\end{array}$ & No \\
\hline $\begin{array}{l}\text { Improve low bank account \& credit } \\
\text { card penetration }\end{array}$ & No \\
\hline Enforce suitable software standards & No \\
\hline $\begin{array}{l}\text { Improve collaboration among the } \\
\text { SMEs }\end{array}$ & \\
\hline
\end{tabular}

The above table shows the support required from outside the organization: external support. Other than the item listed last; "improve collaboration among SMEs" the intermediaries are not capable of proving support with the other barriers. They need to liaise with the government to provide such help to the SME organizations.

The evidence from the above tables is informative. A few barriers; namely, awareness creation and training, appear to be addressed to a certain extent while a majority of the barriers are either disregarded or totally neglected by the participant SME intermediary organizations. It is also evident that where such support is available, it is restricted to the urban areas. Further, there appears to be a disparity between the SMEs' requirements and the support available with the SME intermediaries. The SME intermediaries, on the other hand, seem to be facing trouble, meeting with their objectives. Apparently, this hinders progress with the efforts of the SME intermediaries to assist SMEs. Perhaps this drawback can be attributed to uncoordinated efforts that lack proper strategy, frequent changes of government resulting in changes of rules and regulations, lack of interest from the authorities concerned or may even be due to lethargy from both the public and the private sectors towards heavy investment in what is often seen as an unstable economic environment.

\section{CHALLENGES FACING SMEs}

The objectives of this study were to understand and determine the importance of internal and external barriers; and support required to overcome them. The importance of barriers shows that SMEs are extremely hindered by external barriers. The internal and external support required reveals that there is a strong request for it.

The difference between adoption patterns in developing and developed countries focuses on support activities needed in the development. Support is available in developed countries and it is a matter of finding the appropriate support for a SME encountering barriers, whereas in developing countries this support is almost non-existent. Another difference centers on the external barriers identified, such as the need to improve the national telecommunications infrastructure.

This research contributes by identifying the absence of a government and industry coordinated approach to providing support for SMEs, and not addressing problems at a grass-root level. In addition an initial framework for eTransformation of SMEs in a developing country is proposed for trial towards validation.

\section{Next on the Agenda}

Next, further statistical analysis of survey data attempts to validate initial outcomes, test construct validity, and assumption testing. Barriers and support that predominate at various levels of sophistication need determination for unique perspectives in examining issues and understanding. Problems need to be prioritised at different levels to enable SMEs better equip themselves progress through e-Transformation. Finally the initial framework will be trialled with case study organizations.

\section{CONCLUSION}

This study provides an understanding of the challenges faced by SMEs in the adoption of ICT and e-commerce in developing countries. Assessing and determining current levels of ICT and e-commerce sophistication of SMEs it examines barriers impeding SMEs, while identifying support required for eTransformation. The developed conceptual model identifies internal and external limitations while assessing necessary support to overcome obstacles.

The results of the exploratory interviews and the survey clearly indicate the necessity to provide support to SMEs if they are to successfully adopt ICT and e-commerce. Faced with identified barriers, both external and internal, these barriers are found to impede SME uptake of ICT and e-commerce. Accordingly, necessary support to overcome or alleviate the barriers discovered had also to be recognised. This support, in the form of suggestions were later confirmed in a series of interviews carried out with SME intermediaries whose task is to provide some support, but agree with the existence of many internal and external barriers that prohibit the uptake of ICT or e-commerce by SMEs. The intermediaries go further with their observations. They believe and confirm that SMEs are restricted with the strength or the capacity to address these barriers on their own.

The little available support extended by intermediary organizations at present, seems to be inadequate. Besides, the available support programmes are incapable of meeting SME requirements. It was not surprising, therefore, to note that some SMEs were 
even unaware of the existence of intermediaries, leave alone the support programmes offered by them. Apparently, only a few SMEs have opted to receive assistance from the intermediaries. The identification of a lack of support, an important outcome from the SME intermediary interviews as a possible factor, contributes towards the slow uptake of ICT and e-commerce as explained by them. Their projects do not seem to be sufficiently geared towards the needs of the SMEs. Moreover, it is apparent that activities of such bodies are seen as uncoordinated and bureaucratic. This fact is in agreement with previous research [28].

In an age where information and technology combine to evolve new and emerging technologies that are speedily snapped up by the developed world for their betterment, it is sad to see the developing, trailing behind for the want of necessary financial, and other support. In such a scenario, it is vital that both industry and government step in with the correct advice and support to help SMEs with their uptake of e-commerce. One of the major outcomes of the study presented in this chapter is the necessity to review current initiatives aimed at promoting ICT and e-commerce with the SMEs and to develop strategies with systematic focus to help SMEs to e-Transform their organisations. This information can be fed up to the relevant government authorities to assist them with strategy formation.

\section{References}

1. UNDP (2004). UNCTAD E-Commerce and Development Report 2004.

2. UNCTAD (2001). E-commerce and Development Report.

3. Chong S. (2007). Business process management for SMEs: an exploratory study of implementation factors for the Australian wine industry. Journal of Information Systems and Small Business, 1(1-2): 41-58.

4. Marshall P., Sor R., and McKay J. An idustry case study of the impacts of electronic commerce on car dealership in western Australia. Journal of Electronic Commerce Research 2000. 1(1): 1-16.

5. Rashid M. A. and Al-Qirim N. A. (2001). Ecommerce technology adoption framework by New Zealand small to medium size enterprises. Research Letters Information Mathematical Science, 2(1): 63-70.

6. Cooray M. N. R. (2003) Walk through Cleaner Production Assessment in SME's - A Case Study from Sri Lanka, Small to Medium Enterprise Developers.

7. SLBDC (2002). Survey of electronic commerce implementation on SME sector in Sri Lanka, 2002 Sri Lanka Business Development Centre: Colombo.

8. Chau S.B. and Turner P. (2001). A four Phase Model of EC Business Transformation Amongst Small to Medium Enterprises. 12th Australian Conference on Information Systems. Coffs Harbour, Australia.

9. Mehrtens J., Cragg P.B. and Mills A. (2001). A model of internet adoption by SMEs. Information and Management, 39(3): 165-176.

10. Jacovou C.L., Benbasat I. and Dexter A.S. (1995). Electronic Data interchange and Small organizations: Adoption and impact of technology. MIS Quaterly, 19(4): 465-485.

11. Akkeren V. J. and Cavaye A. L. M. (1999). Factors affecting entry-level internet technology adoption by small business in Australia - evidence from three cases. Journal of Systems and Information Technology, 3(2): 33-48.

12. Cloete E., Courtney S. and Fintz J. (2002). Small business acceptance and adoption of e-commerce in the Western-Cape province of South-Africa. Electronic Journal of Information Systems in Developing Countries, 10(4): 1-13.

13. EBPG, (2002), eEurope go digital: Benchmarking national and regional e-bussiness policies for SMEs, Final report of the E-Business Policy Group, European Commission, Enterprise Directorate General, Brussels, 28 June 2002.

14. Corbitt B., Behrendorf G., and Brown-Parker J. (1997). Small - and Medium-Sized Enterprises and Electronic Commerce. The Australian Institute of Management, 14 (204-22).

15 Huff S. and Yoong P. (2000). SMEs and Ecommerce: Current Issues and Concerns. A Preliminary Report in International Conference on E-commerce, Kuala Lumpur, Malaysia.

16. OECD. (1998). SMEs and electronic commerce, Ministerial Conference on Electronic Commerce. Ottawa, Canada.

17. Anigan G., (1999). Views on Electronic Commerce. International Trade Forum, 2: 23-27.

18. Bingi P., Mir A. and Khamalah J. (2000) The Challenges Facing GlobalE-Commerce Information Systems Management, 17(4): 26-35.

19. Elkin N. (2001). Online Privacy and Security in Latin America. 
20. El-Nawawy M.A. and Ismail M.M. (1999). Overcoming Deterrents and Impediments to Electronic Commerce in Light of Globalisation: The Case of Egypt. 9th Annual Conference of the Internet Society, INET 99, San Jose, USA,.

21. Schmid B., Stanoevska-Slabeva K. and Tschammer V. Towards (2001) the E-Society: E-Commerce, E-Business, E-Government. 2001: Zurich, Switzerland.

22. Mingers J., (2001). Combining IS Research Methods: Towards a Pluralist Methodology. Information Systems Research, 12(3): 240-259.

23. Gable G.G., Dharshana S. and Taizan C. (2003). Enterprise Systems Success; A Measurement Model. 24th International Conference on Information Systems 2003.

24. Gallivan M. J., (2001). Organisational Adoption and Assimilation of Complex Technological Innovations; Development and Application of a New Framework. The DATABASE for Advances in Information Systems, 32(3): 51-85.

25. Sekaran U.,(2000) Research Methods for Business - A Skill Building Approach. 3rd Edition ed. 2000: John Wiley \& Sons, Inc.

26. Kapurubandara M. and Lawson. R. (2007). SMEs in Developing Countries Need Support to Address the Challenges of Adopting e-commerce Technologies. 20th Bled eConference eMergence: Merging and Emerging Technologies, Processes, and Institutions. Bled, Slovenia, June 4 - 6.

27. Task Force. (2002). National Strategy for Small and Medium Enterprise Sector Development in Sri Lanka. Task Force for Small \& Medium Enterprise Sector Development Program,Reports Prepared under the IPS Leadership for the GOSL

28. Lewis R. and Cockrill A. (2002). Going globalremaining local: The impact of e-commerce on small retail firms in Wales. International Journal of Information Management, 22(3): 195-209. 